\title{
ACAROLOGY
}

\section{Life History of Amblyseius herbicolus (Chant) (Acari: Phytoseiidae) on Coffee Plants}

\author{
Paulo R. Reis ${ }^{1}$, Adenir V. Teodoro ${ }^{2}$, Marçal Pedro Neto ${ }^{2}$ and Ester A. Da Silva 3 \\ ${ }^{1}$ EPAMIG-CTSM/EcoCentro, C. postal 176, 37200-000, Lavras, MG, CNPq Researcher \\ paulo.rebelles@epamig.ufla.br \\ ${ }^{2} U F L A$, . postal 3037, 37200-000 Lavras, MG. Fapemig and CBP\&D/Café Research Assistantship Recipients \\ ${ }^{3}$ Univ. Estadual do Maranhão, 65055-150, São Luís, MA
}

Neotropical Entomology 36(2):282-287 (2007)

\author{
História de Vida de Amblyseius herbicolus (Chant) (Acari: Phytoseiidae) em Cafeeiro
}

\begin{abstract}
RESUMO - O ácaro predador Amblyseius herbicolus (Chant) é o segundo fitoseídeo mais abundante em cafeeiro (Coffea arabica L.), após Euseius alatus DeLeon, na região de Lavras, MG, associado ao vetor do vírus da mancha-anular, Brevipalpus phoenicis (Geijskes) (Acari: Tenuipalpidae). Sua história de vida foi estudada levando em conta aspectos biológicos, tabela de vida, atividade predatória e respostas funcional e numérica em função da densidade de presa. Foi constatada longevidade de 38 dias para fêmeas adultas quando alimentadas com $B$. phoenicis. A estimativa da capacidade inata de crescimento da população $\left(\mathrm{r}_{\mathrm{m}}\right)$ foi 0,150 e a duração média de uma geração $(\mathrm{T})$ 25,3 dias. A população dobrou a cada 4,6 dias. Trinta ácaros B. phoenicis /arena de folha de cafeeiro ( $3 \mathrm{~cm}$ de diâmetro) foram oferecidos separadamente para um espécime de cada fase do ácaro predador. Fêmeas adultas foram mais eficientes na predação de todas as fases do desenvolvimento do ácaro-presa, seguidas das fases ninfais. Para o estudo das respostas funcional e numérica, a presa foi oferecida nas densidades de 0,14 a 42,3 formas imaturas de $B$. phoenicis $/ \mathrm{cm}^{2}$ de arena, por serem preferidas para predação. A predação e oviposição de $A$. herbicolus aumentam com o aumento da densidade de presa, com uma correlação positiva e altamente significativa. A análise de regressão realizada sugere uma resposta funcional do tipo II, com uma predação máxima diária de aproximadamente $35 \mathrm{~B}$. phoenicis $/ \mathrm{cm}^{2} /$ fêmea adulta.
\end{abstract}

PALAVRAS-CHAVE: Biologia, fitoseídeo, resposta funcional, resposta numérica, Coffea arabica

\begin{abstract}
The predaceous mite Amblyseius herbicolus (Chant) is the second most abundant phytoseiid on coffee plants (Coffea arabica L), after Euseius alatus DeLeon, in Lavras, MG, Brazil, associated to the vector of the coffee ring spot virus, Brevipalpus phoenicis (Geijskes) (Acari: Tenuipalpidae). Its life history was studied taking into account biological aspects, life table, predatory activity and functional and numerical responses in relation to the density of the prey. The adult female has longevity of 38 days when supplied with B. phoenicis. The intrinsic rate of population increase $\left(\mathrm{r}_{\mathrm{m}}\right)$ was 0.150 and the mean generation time (T) 25.3 days. The population doubles every 4.6 days. Thirty mites B. phoenicis $/ 3-\mathrm{cm}$ diameter coffee leaf arenas were separately offered to one specimen of each predator phase. Adult females were more efficient in killing all developmental phases of B. phoenicis, followed by the nymph stages. For the functional and numerical responses studies, from 0.14 to 42.3 immature specimens of the prey $/ \mathrm{cm}^{2}$ of arena were submitted to the predator, the preferred phase for predation. Predation and the oviposition of $A$. herbicolus increased with increasing prey density, with a positive and highly significant correlation. Regression analysis suggests a functional type II response, with a maximum daily predation near 35 B. phoenicis $/ \mathrm{cm}^{2} /$ one adult female.
\end{abstract}

KEY WORDS: Biology, phytoseiid, functional response, numerical response, Coffea arabica

Phytoseiid mites are the most important and one of the most studied natural enemies of pest mites (McMurtry et al. 1970, Moraes 1991, McMurtry \& Croft 1997) factor to be considered in integrated pest management. The predatory mite Amblyseius herbicolus (Chant) (Acari: Phytoseiidae) is one of the more frequent and abundant phytoseiid in
Brazilian coffee crops (Coffea arabica L.) associated to the pest mites Brevipalpus phoenicis (Geijskes) (Acari: Tenuipalpidae) and Oligonychus ilicis (McGregor) (Acari: Tetranychidae) (Pallini et al. 1992, Reis 2002).

Moraes et al. (1991) reported 55 species (A. herbicolus among them) of phytoseiids in Latin America, and Lin et 
al. (2000) cited its presence in China. This species was also found in Brazil associated to Arecaceae (Santana \& Flechtmann 1998, Gondim \& Moraes 2001), Euphorbiaceae (Zacarias \& Moraes 2001), and native plants of the State of Rio Grande do Sul (Ferla \& Moraes 2002).

The predaceous $A$. herbicolus was cited previously as Typhlodromus (Amblyseius) herbicolus Chant, Amblyseius deleoni Muma \& Denmark and Amblyseius impactus Chaudhri, according to Gondim \& Moraes (2001), Zacarias $\&$ Moraes (2001) and Moraes et al. (2004).

A question raised is if phytoseiids can reduce high population densities of phytophagous mites, and the studies that answer such question are those of functional (number of prey consumed per time unit) and numerical (progeny produced by time unit or other change in predator density) responses (Solomon 1949, Mori \& Chant 1966, Laing \& Osborn 1974). The last two authors found that the two responses are correlated and should be considered together.

Holling $(1959,1961)$ reported that three basic types of functional response to prey density could be identified in general: linear, convex and sigmoid. In type I (linear) the number of prey consumed increases linearly up to a maximum; in type II (convex) the number of consumed prey increases with the number of prey offered but begins to decrease when a maximum point is reached, that is, begins to show a reduction in consumed prey rate with the increase of its density, and in type III (sigmoid) predation result in a sigmoid form with the increase of prey density up to a maximum. The first type of response is supposedly typical in aquatic invertebrates, the second in predator and parasitoids arthropods and the third of vertebrate predators (Hassel 1978).

According to Holling (1959) the basic factors that affect functional response are: the time of exposure to predator and prey, search rate, identification, capture, and prey consumption. Other factors like predator stimulation due to prey interference or the kind of learning response (Sandness \& McMurtry 1970), the confusion effect and hunger are subsidiary but important because they can trigger part or all basic factors.

As for the life table determination it's known that they help both, as in the dynamics population species comprehension and in the natural enemies impact evaluation causes over population (Lenteren \& Woets 1988, Bellows Jr et al. 1992). Yet, life table, functional and numerical responses are basic requirements for the evaluation of the predatory potential of a predator for its use as biological control agent (Thongtab et al. 2001).

Among phytophagous mites, B. phoenicis is considered of great importance in Brazil as citrus leprosis (Chiavegato et al. 1982) and coffee ring spot virus vector (Chagas 1973). The control threshold for this species is very low because it is a disease vector, resulting in frequent sprays of coffee crops with phytossanitary products which bring, as a consequence in most cases, failure due to resistance acquired easily by the mites to the product used, in addition to the biological disruption caused to the environment.

This work was carried out to evaluate the predatory potential of $A$. herbicolus as biological control agent of $B$. phoenicis through studies of its biology, fertility life table, predatory capacity and study of functional and numerical responses.

\section{Material and Methods}

All bioassays and rearing of mites were carried out under $25 \pm 2^{\circ} \mathrm{C}, 70 \pm 10 \% \mathrm{RH}$ and $14 \mathrm{~h}$ photophase in the Laboratório de Acarologia of the Centro de Pesquisa em Manejo Ecológico de Pragas e Doenças de Plantas - EcoCentro, of the Empresa de Pesquisa Agropecuária de Minas Gerais - EPAMIG, located at the Universidade Federal de Lavras - UFLA campus.

Stock rearing. All mites, predator and prey, used in the functional and numerical responses bioassays were collected in the field in a crop of the Catuai cultivar of coffee $(C$. arabica), which had received no phytossanitary treatments for the past three years, and kept in the laboratory as maintenance rearing.

Stock rearing of $A$. herbicolus to be used in the experiments was made in arenas which consisted of $6-\mathrm{cm}$ coffee leaf disks floating in distilled water in $15-\mathrm{cm}$ diameter petri dishes. In the middle of each arena there was a small hole to allow the passage of a pin that was glued with the head on the bottom of the dish, with adhesive of silicon, and with the point up. This allowed the arenas to move inside of the petri dish fluctuating up and down according to the water level, preventing them of touching the border of the dishes. Each arena contained a $20 \times 20-\mathrm{mm}$ microscope slide cover glass over cotton fibers, which served as shelter, oviposition site and local for placing pollen of castor bean plant (Ricinus communis L.) (Reis \& Alves 1997). Pollen and immature stages of $B$. phoenicis were supplied to the mites.

The stock rearing of $B$. phoenicis in the laboratory was made on paraffin-coated citrus fruits (Citrus sinensis Osbeck) except in approximately $3-\mathrm{cm}$ diameter areas. These areas were cleaned up by using a small brush and immediately surrounded by a BioStick ${ }^{\circledR}$ barrier to prevent mites from escaping (Chiavegato 1986).

Biological aspects. Data referring to the biology of $A$. herbicolus were obtained in 3-cm diameter arenas, made with coffee leaf from the third apical pair and branches from the median third plant part, fluctuating in distilled water in 15$\mathrm{cm}$ petri dishes, according to methodology reported by Reis et al. (1998) for biological studies of Iphiseiodes zuluagai Denmark \& Muma (Acari: Phytoseiidae). Observations were daily made at 8 am and $4 \mathrm{pm}$. Egg, larva, protonymph and deutonymph stage duration were evaluated, as well as adult female longevity. Nourishment was the same used in stock rearing, except pollen, in other words, B. phoenicis immature stages only.

Fertility life table. Fertility life table for the predatory mite was built using survival data $(l)$, specific fertility $(m)$ and sex ratio (Birch 1948, Dinh et al. 1988), after female deutonymphs. Each deutonymph was placed on a $3-\mathrm{cm}$ in diameter arena of coffee leaf (Reis et al. 1998) and observed 
at $24 \mathrm{~h}$ intervals, removing the eggs laid and registering the dead mites. Twenty-two females originated from the stock rearing were observed. Thirty immatures of B. phoenicis by day, both larvae and nymphs, were supplied to the predaceous mite.

The following parameters were calculated: $\mathrm{R}_{\mathrm{o}}=\sum m_{x} \cdot l_{x}$ (net reproductive rate or the number of times to the population increases in each generation); $\mathrm{T}=\sum m_{x} \cdot l_{x} \cdot x / \sum m_{x} \cdot l_{x}$ (mean generation time) $\mathrm{r}_{\mathrm{m}}$ (approximate) $=\ln \mathrm{R}_{\mathrm{o}} / \mathrm{T}$ (estimate of the intrinsic rate of population increase) and $\lambda=e^{\mathrm{rm}}$ (finite rate of increase, which represents the number o individuals added to the population /time unit /female which will originate a female).

The true value of $r_{m}$ was calculated interactively through Lotka equation (Carey 1993):

$$
\sum_{x=0}^{T} l_{x} m_{x} e^{-r_{m}(x+1)}=1
$$

After obtaintion of the true value of $r_{m}$, the mean duration of one generation was recalculated, $\mathrm{T}=\ln \mathrm{R}_{\mathrm{o}} / \mathrm{r}_{\mathrm{m}}$.

The number of days needed for the population to duplicate was also calculated, and according to Tanigoshi et al. (1975) is equal to $\ln 2 / r_{m}$.

Predatory activity. The experiments were conducted in $3-\mathrm{cm}$ diameter arenas of coffee leaf, fluctuating in distilled water in $15-\mathrm{cm}$ diameter petri dishes (Reis et al. 2000). Four experiments were performed, one for each phase of development of B. phoenicis - egg, larva, nymph (protonymph plus deutonymph) and adult - with a completely randomized design and five treatments: control, larva, nymph and $A$. herbicolus adult female. Thirty $B$. phoenicis were placed /arena, for one predaceous mite specimen according to the phase to be tested, with 10 replicates. After $24 \mathrm{~h}$ following the introduction of the mites in the arenas, predated, partially predated, naturally dead, dead in water and live $B$. phoenicis were counted. Both, predator and prey species were obtained from the stock rearing which allows to obtain mites of the same age.

Functional and numerical responses. An adult female of $A$. herbicolus was confined during eight days in a 3-cm diameter coffee leaf arena $\left(7.1 \mathrm{~cm}^{2}\right)$ fluctuating in distilled water in a $15-\mathrm{cm}$ diameter and $2-\mathrm{cm}$ deep petri dish. Eight arenas were placed in each dish at equal distances from each other and kept in place by a small hole in the middle to accommodate an upside down pin with the head glued in the bottom, described previously. Immatures of $B$. phoenicis were placed in the following densities $0.14,0.28,0.70,1.4,2.8,4.2,4.9$ (with seven replicates); 6.3 (with four replicates); 7.7 (with three replicates); 9.8, 14.1, 17.6, 28.2 and $42.3 / \mathrm{cm}^{2}$ (with two replicates). Larvae and nymphs were used due to the preference for immature stages of the prey for predation by phytoseiids (Gravena et al. 1994, Reis et al. 2000). The same number of $B$. phoenicis was used as control treatment in the arenas, but in absence of the predator for natural mortality observation.
The number of dead prey and eggs laid by the predatory mite were evaluated every $24 \mathrm{~h}$ with removal of dead prey not consumed and eggs. The number of prey was brought to the original one every day during eight days.

\section{Results and Discussion}

Biological aspects. The average duration of egg stage was $1.5 \pm 0.31$ days, with $100 \%$ viability. Other developmental stage average durations were $1.2 \pm 0.31$ days for the larvae, $1.0 \pm 0.26$ day for the protonymph and $1.3 \pm 0.32$ days for the deutonymph. Development from egg to adult was lasted $6.9 \pm 0.64$ days and female longevity $37.9 \pm 5.47$ days (Table $1)$. The sex ratio was equal to 1 (100\% of females) and no males was found in $A$. herbicolus colonies. The absence of $A$. herbicolus males was related in other papers, confirming therefore the reproduction of this species by telitoky (Moraes \& Mesa 1988).

Fertility life table. The intrinsic rate of population increase of the predator $\left(\mathrm{r}_{\mathrm{m}}\right)$ was 0.150 female /female /day; the mean generation time $(\mathrm{T}) 25.3$ days; the net reproductive rate $\left(R_{0}\right)$ 44.8 females /female and the finite rate of increase $(\lambda) 1.16$. The population is estimated to double every 4.6 days. These results demonstrate that this species is well adapted to $B$. phoenicis, presenting higher predation than I. zuluagai (Reis et al. 1998). Under laboratory conditions, considered ideal and where there is appropriate nourishment, the predator can show high reproduction capacity. On the other hand, under field conditions, one can state that several ecological factors can interfere with its reproductive capacity. It is known that, as higher is the finite increase rate higher will be the daily growth of the population, and the one showed by $A$. herbicolus $(\lambda=$ 1.16) is slighter higher than for I. zuluagai $(\lambda=1.13)$ (Reis et al. 1998), species also frequently founded on coffee crops (Pallini et al. 1992, Reis 2002).

Predatory activity. Only nymphs and adults of $A$. herbicolus predate adults of $B$. phoenicis, but they consumed less than $30 \%$ of the 30 mites offered. Adult female was the most efficient in predating all phases of development of the prey,

Table 1. Duration in days (mean \pm standard error) of all developmental phases of $A$. herbicolus fed on B. phoenicis, under $25 \pm 2^{\circ} \mathrm{C}, 70 \pm 10 \% \mathrm{RH}$ and $14 \mathrm{~h}$ photofase.

\begin{tabular}{lcc}
\hline Phases of life cycle & $\mathrm{n}$ & Mean \pm SE (days) \\
\hline Egg stage & 68 & $1.50 \pm 0.31$ \\
Larva & 67 & $1.16 \pm 0.31$ \\
Protonymph & 67 & $1.00 \pm 0.26$ \\
Deutonymph & 64 & $1.26 \pm 0.32$ \\
Egg - adult & 64 & $6.88 \pm 0.64$ \\
Longevity (female) & 64 & $37.9 \pm 5.47$ \\
\hline
\end{tabular}

$\mathrm{n}=$ Number of studied mites. 
although nymphs showed also high predation (Fig. 1), similar to the results obtained with other species of phytoseiids (Gravena et al. 1994, Reis et al. 2000).

Functional and numerical responses. Results show that predation and oviposition of $A$. herbicolus increases according to the increase in prey population density, with a positive and highly significant correlation (with the determination coefficient equals to $0.98 * *$ and $0.97 * *$, respectively), with almost $100 \%$ consumption in the population density of $7.7 \mathrm{~B}$. phoenicis $/ \mathrm{cm}^{2}$, and egg laying of 1.7 eggs /day from 14.1 to 42.3 prey $/ \mathrm{cm}^{2}$ (Table 2; Figs. 2 and 3). Although the number of $B$. phoenicis killed increase with the increase of density of the mites offered, the percent of attack reduces (Fig. 4), similar to the results showed by Reis et al. (2003) with other two species of phytoseiids. Such fact may result from their satiety or interference on their predation capacity related to prey density (Mori \& Chant 1966, Sandness \& McMutry 1970), suggesting that $A$. herbicolus will be more efficient under low and medium prey densities. Predator-prey models in general support the idea that control by predation is very efficient, particularly under low prey density, and the mites of the group Gamasina, important group of predatory mites, are included in this class (Koehler 1999).

The regression analysis suggests a functional type II response, with a maximum daily predation near to $35 \mathrm{~B}$. phoenicis $/ \mathrm{cm}^{2}$ /one female (Fig. 2) which, according to Hassel (1978), is typical in predatory arthropods.

Sandness \& McMurtry (1970) observed that Amblyseius largoensis (Muma) (Acari: Phytoseiidae), species taxonomically close to A. herbicolus was more efficient in killing Oligonychus punicae (Hirst) (Acari: Tetranychidae)

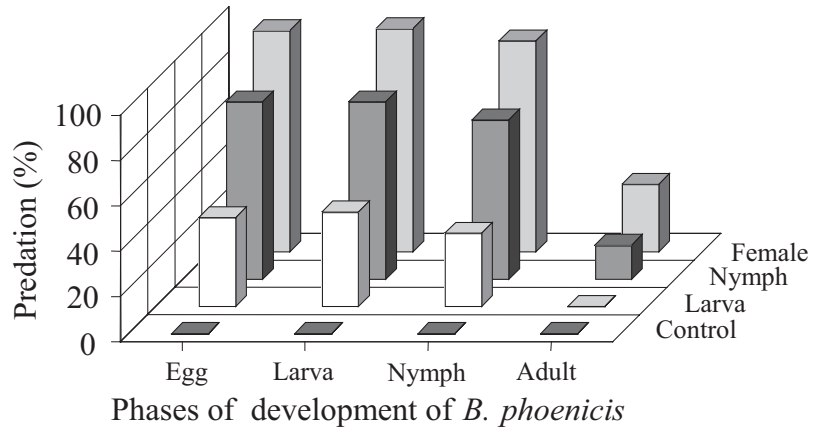

Fig. 1. Percent predation of $B$. phoenicis, on its different development stages, by larva, nymph and adult female of the predatory mite $A$. herbicolus.

when compared to Euseius concordis (Chant) and Galendromus floridanus (Muma) (Acari: Phytoseiidae).

$A$. herbicolus was shown to be an efficient predatory mite at several densities of the coffee ring spot mite, $B$. phoenicis. Its importance as an efficient natural enemy was evidenced and, therefore, among other predatory mites, it must be preserved through integrated and agroecological management programs.

\section{Acknowledgments}

To the Consórcio Brasileiro de Pesquisas e Desenvolvimento do Café - CBP\&D/Café for the financial support and scholarship, and to the Fundação de Amparo à

Table 2. Functional and numerical responses of the predatory mite $A$. herbicolus fed on the phytophagous mite $B$. phoenicis, under $25 \pm 2^{\circ} \mathrm{C}, 70 \pm 10 \%$ de $\mathrm{RH}$ and $14 \mathrm{~h}$ photophase.

\begin{tabular}{|c|c|c|c|c|c|c|}
\hline \multirow{2}{*}{$\begin{array}{l}\text { Prey density } \\
\left(\text { mites } / \mathrm{cm}^{2}\right)\end{array}$} & \multicolumn{2}{|c|}{ Mean $\pm \mathrm{SE}$} & \multicolumn{2}{|c|}{ Range } & \multirow[b]{2}{*}{ Predation $(\%)$} & \multirow[b]{2}{*}{ Natural mortality (\%) } \\
\hline & $\begin{array}{l}\text { Consumption } \\
\text { (preys /day) }\end{array}$ & Eggs laid /day & Preys & Eggs & & \\
\hline 0.14 & $0.86 \pm 0.06$ & $0.14 \pm 0.01$ & $0-1$ & $0-1$ & 86.00 & 0.00 \\
\hline 0.28 & $1.93 \pm 0.10$ & $0.27 \pm 0.03$ & $1-2$ & $0-1$ & 96.50 & 0.00 \\
\hline 0.7 & $4.92 \pm 0.08$ & $0.25 \pm 0.06$ & $4-5$ & $0-2$ & 98.40 & 0.00 \\
\hline 1.4 & $9.87 \pm 0.50$ & $0.23 \pm 0.06$ & $7-10$ & $0-2$ & 98.70 & 0.00 \\
\hline 2.8 & $19.37 \pm 0.03$ & $0.60 \pm 0.09$ & $14-20$ & $0-2$ & 96.85 & 0.00 \\
\hline 4.2 & $28.14 \pm 1.20$ & $0.75 \pm 0.09$ & $17-30$ & $0-2$ & 93.80 & 4.17 \\
\hline 4.9 & $33.07 \pm 1.20$ & $1.09 \pm 0.10$ & $15-35$ & $0-3$ & 94.48 & 1.07 \\
\hline 6.3 & $43.78 \pm 1.15$ & $1.22 \pm 0.09$ & $38-45$ & $0-2$ & 97.29 & 0.28 \\
\hline 7.7 & $54.50 \pm 2.69$ & $1.08 \pm 0.12$ & $53-55$ & $0-2$ & 99.09 & 1.59 \\
\hline 9.8 & $61.68 \pm 2.50$ & $1.43 \pm 0.15$ & $50-70$ & $1-2$ & 88.11 & 0.71 \\
\hline 14.1 & $87.37 \pm 2.35$ & $1.68 \pm 0.18$ & $70-96$ & $1-2$ & 87.37 & 2.00 \\
\hline 17.6 & $82.99 \pm 2.65$ & $1.56 \pm 0.17$ & $68-96$ & $1-3$ & 66.39 & 1.80 \\
\hline 28.2 & $101.50 \pm 3.05$ & $1.62 \pm 0.17$ & $88-120$ & $1-3$ & 50.75 & 0.19 \\
\hline 42.3 & $127.81 \pm 6.01$ & $1.68 \pm 0.18$ & $82-184$ & $1-3$ & 42.60 & 3.46 \\
\hline
\end{tabular}




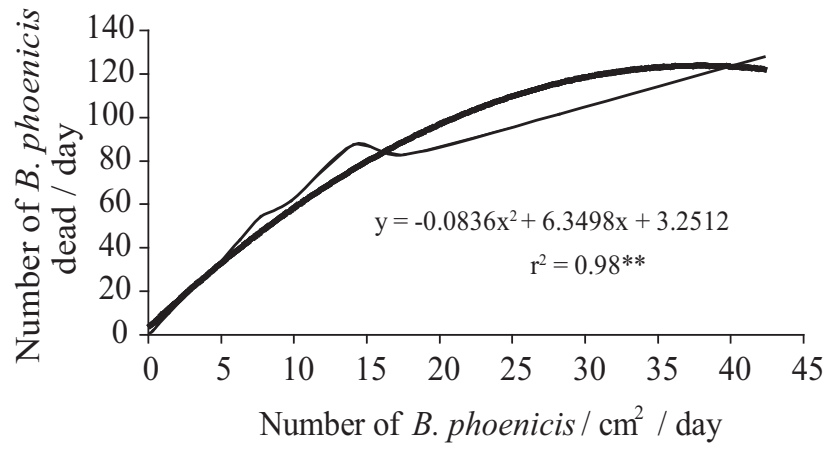

Fig. 2. Number of $B$. phoenicis preyed upon by one female of $A$. herbicolus according to the density offered.

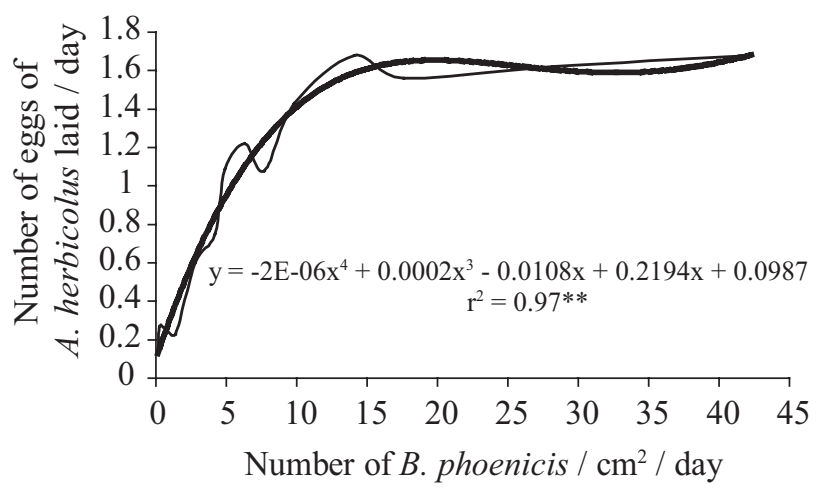

Fig. 3. Number of eggs laid by one female of $A$. herbicolus according to the density of $B$. phoenicis offered.

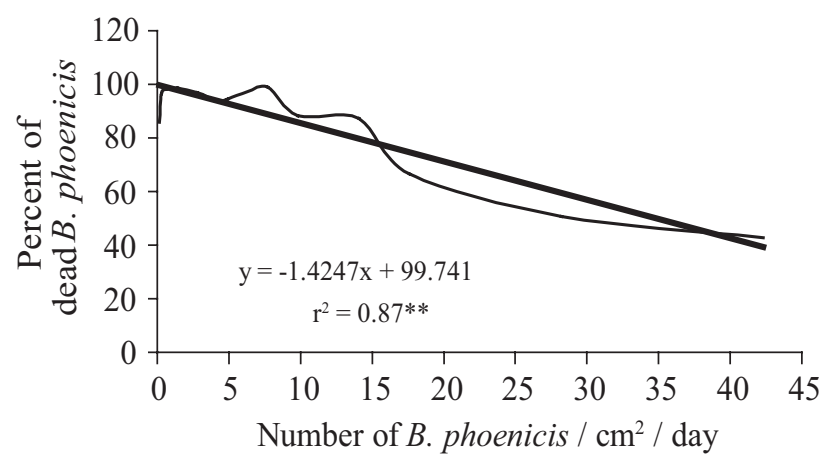

Fig. 4. Percent of $B$. phoenicis preyed upon by one female of $A$. herbicolus according to the density offered.

Pesquisa do Estado de Minas Gerais - Fapemig and Conselho Nacional de Desenvolvimento Científico e Tecnológico $\mathrm{CNPq}$ for the scholarships granted.

\section{References}

Bellows Jr, T.S., R.G. van Driesche \& J.S. Elkinton. 1992. Life-table construction and analysis in the evaluation of natural enemies. Annu. Rev. Entomol. 37: 587-614.
Birch, L.C. 1948. The intrinsic rate of natural increase of an insect population. J. Anim. Ecol. 17: 15-26.

Carey, J.R. 1993. Applied demography for biologists with special emphasis on insects. New York, Oxford University Press. 206p.

Chagas, C.M. 1973. Associação do ácaro Brevipalpus phoenicis (Geijskes) à mancha-anular do cafeeiro. Biológico 39: 229232.

Chiavegato, L.G. 1986. Biologia do ácaro Brevipalpus phoenicis em citros. Pesqu. Agropec. Bras. 21: 813-816.

Chiavegato, L.G., M.M. Mischan \& M.A. Silva. 1982. Prejuízos e transmissibilidade de sintomas de leprose pelo ácaro Brevipalpus phoenicis (Geijskes, 1939) Sayed, 1946 (Acari, Tenuipalpidae) em citros. Científica 10: 265-271.

Dinh, N. van, A. Janssen \& M.W. Sabelis. 1988. Reproductive success of Amblyseius idaeus and A. anonymus on a diet of two-spotted spider mites. Exp. Appl. Acarol. 4: 41-51.

Ferla, N.J. \& G.J. de Moraes. 2002. Ácaros predadores (Acari) em plantas nativas e cultivadas do Estado do Rio Grande do Sul, Brasil. Rev. Bras. Zool. 19:1011-1031.

Gondim Jr, M.G.C. \& G.J. de Moraes. 2001. Phytoseiid mites (Acari) associated with palm trees (Arecaceae) in Brazil. Syst. Appl. Acarol. 6: 65-94.

Gravena, S., I. Benetoli, P.H.R. Moreira \& P.T. Yamamoto. 1994. Euseius citrifolius Denmark \& Muma predation on citrus leprosis mite Brevipalpus phoenicis (Geijskes) (Acari: Phytoseiidae, Tenuipalpidae). An. Soc. Entomol. Bras. 23: 209-218.

Hassel, M.P. 1978. The dynamics of arthropod predator-prey systems. Princeton, Princeton University Press, 237p.

Holling, C.S. 1959. The components of predation as revealed by a study of small-mammal predation of the European pine sawfly. Can. Entomol. 91: 293-329.

Holling, C.S. 1961. Principles of insect predation. Annu. Rev. Entomol. 6: 163-182.

Koehler, H.H. 1999. Predatory mites (Gamasina, Mesostigmata). Agric. Ecosyst. Environ. 74: 395-410.

Laing, J.E. \& J.A.L. Osborn. 1974. The effect of prey density on the functional and numerical response of three species of predatory mites. Entomophaga 19: 267-277.

Lenteren, J.C. van \& J. Woets. 1988. Biological and integrated pest control in green houses. Annu. Rev. Entomol. 33: 239-269.

Lin, J., Z.Q. Zhang, Y.X. Zhang, Q.Y. Liu \& J. Ji. 2000. Checklist of mites from moso bamboo in Fujian, China. Syst. Appl. Acarol. Spec. Publ. 4: 81-92.

McMurtry, J.A. \& B.A. Croft. 1997. Life-styles of phytoseiid mites and their roles in biological control. Annu. Rev. Entomol. 42: 291-321.

McMurtry, J.A., C.B. Huffaker \& M. van de Vrie. 1970. Ecology of tetranychid mites and their natural enemies: A review. I. Tetranychidae enemies: Their biological characters and the impact of spray practices. Hilgardia 40: 331-390. 
Moraes, G.J. de. 1991. Controle biológico de ácaros fitófagos. Inf. Agropec. 15: 56-62.

Moraes, G.J. de, J.A. McMurtry, H.A. Denmark \& C.B. Campos. 2004. A revised catalog of the mite family Phytoseiidae. Auckland, Magnolia Press, 494p. (Zootaxa 434).

Moraes, G.J. de \& N.C. Mesa. 1988. Mites of the family Phytoseiidae (Acari) in Colombia, with descriptions of three new species. Int. J. Acarol. 14: 71-88.

Moraes, G.J. de, N.C. Mesa \& A. Braun. 1991. Some phytoseiid mites of Latin America (Acari: Phytoseiidae). Int. J. Acarol. 17: 117-139.

Mori, H. \& D.A. Chant. 1966. The influence of prey density, relative humidity and starvation on the predacious behavior of Phytoseiulus persimilis Athias-Henriot (Acarina: Phytoseiidae). Can. J. Zool. 44: 483-491.

Pallini Filho, A., G.J. de Moraes \& V.H.P. Bueno. 1992. Ácaros associados ao cafeeiro (Coffea arabica L.) no Sul de Minas Gerais. Ciênc. Agrotecnol. 16: 303-307.

Reis, P.R. 2002. Brevipalpus phoenicis, ácaro vetor da manchaanular em cafeeiro: Bioecologia, dano e controle, p.257-280. In R. de O. Encarnação, P.C. Afonso Jr \& J.L. dos S. Rufino (coords.), Palestras do I Simpósio de Pesquisa dos Cafés do Brasil. Brasília, Embrapa Café. 347p.

Reis, P.R., A.V. Teodoro \& M. Pedro Neto. 2000. Predatory activity of phytoseiid mites on the developmental stages of coffee ring spot mite (Acari: Phytoseiidae: Tenuipalpidae). An. Soc. Entomol. Bras. 29: 547-553.

Reis, P.R. \& E.B. Alves. 1997. Criação do ácaro predador Iphiseiodes zuluagai Denmark \& Muma (Acari: Phytoseiidae) em laboratório. An. Soc. Entomol. Bras. 26: 565-568.
Reis, P.R., E.O. Sousa, A.V. Teodoro \& M. Pedro Neto. 2003. Effect of prey density on the functional and numerical response of two species of predaceous mites (Acari: Phytoseiidae). Neotrop. Entomol. 32: 461-467.

Reis, P.R., L.G. Chiavegato \& E.B. Alves. 1998. Biologia de Iphiseiodes zuluagai Denmark \& Muma (Acari: Phytoseiidae). An. Soc. Entomol. Bras. 27: 185-191.

Sandness, J.N. \& J.A. McMurtry. 1970. Functional response of three species of Phytoseiidae (Acarina) to prey density. Can. Entomol. 102: 692-704.

Santana, D.L.Q \& C.H.W. Flechtmann. 1998. Mite (Arthropoda, Acari) associates of palms (Arecaceae) in Brazil. I. Present status and new records. Rev. Bras. Zool. 15:959-963.

Solomon, M.E. 1949. The natural control of animal populations. J. Anim. Ecol. 18: 1-35.

Tanigoshi, L.K., S.C. Hoyt, R.W. Browne \& J.A. Logan. 1975. Influence of temperature on population increase of Metaseiulus occidentalis (Acarina: Phytoseiidae). Ann. Entomol. Soc. Am. 68: 979-986.

Thongtab, T., A. Chandrapatya \& G.T. Baker. 2001. Biology and efficacy of the predatory mite, Amblyseius longispinosus (Evans) (Acari, Phytoseiidae) as a biological control agent of Eotetranychus cendanai Rimando (Acari, Tetranychidae). J. Appl. Entomol. 125: 543-549.

Zacarias, M.S. \& G.J. de Moraes. 2001. Phytoseiid mites (Acari) associated with rubber trees and other euphorbiaceous plants in southeastern Brazil. Neotrop. Entomol. 30: 579-586.

Received 12/IX/05. Accepted 27/VII/06 